\title{
Change of Heating Value, pH and FT-IR Spectra of Charcoal at Different Carbonization Temperatures ${ }^{* 1}$
}

\author{
Sung-Min Kwon*2, Jae-Hyuk Jang*2, Seung-Hwan Lee*2, Sang-Bum Park*3, \\ and Nam-Hun Kim*2+
}

\begin{abstract}
To understand transition characteristics from wood to charcoal, Quercus variabilis wood was carbonized at $200,250,300,340,540$ and $740^{\circ} \mathrm{C}$, respectively. Heating value, $\mathrm{pH}$ and surface property by FT-IR spectroscopy of the carbonized charcoal were investigated. Heating value and $\mathrm{pH}$ increased with increasing carbonization temperature from $4500 \mathrm{cal} / \mathrm{g}$ and 4.3 of the control wood to $8,000 \mathrm{cal} / \mathrm{g}$ and 9 of the charcoal carbonized at $740^{\circ} \mathrm{C}$, respectively. From FT-IR spectroscopy, the peaks from $\mathrm{O}-\mathrm{H}, \mathrm{C}-\mathrm{H}$ and $\mathrm{C}-\mathrm{O}$ stretching disappeared during carbonization at 540 and $740^{\circ} \mathrm{C}$. Aromatic skeletal vibration at near $1,506 \sim 1,593 \mathrm{~cm}^{-1}$ was repidly increased until $540^{\circ} \mathrm{C}$. These results suggest that the chemical and physical characteristics of wood components in cell wall can be easily changed by increasing carbonization temperature and the carbonization seem to be incomplete at temperature below $540^{\circ} \mathrm{C}$.
\end{abstract}

Keywords : carbonization, charcoal, heating value, pH, FT-IR

\section{INTRODUCTION}

Charcoal can be generally produced when wood is heated in the absence of oxygen. In this process, the water contained in the wood is first driven off before the wood constituents (cellulose, hemicellulose and lignin) begin to be thermally decomposed. Wood pyrolysis is a complex combination with the individual pyrolysis of cellulose, hemicellulose, lignin and extractives, each of which has its own characteristics (Kwon et al., 2009).
Zeriouh and Belkbir (1995) reported that, in the pyrolysis process of wood constituents with heating rate of $5^{\circ} \mathrm{C} \mathrm{min}{ }^{-1}$, hemicellulose is decomposed at the temperatures ranging 170 $240^{\circ} \mathrm{C}$, cellulose $240 \sim 310^{\circ} \mathrm{C}$ and lignin $320 \sim$ $400^{\circ} \mathrm{C}$. Between $260^{\circ} \mathrm{C}$ and $400^{\circ} \mathrm{C}$, almost $80 \%$ of the total weight loss occurs, which may vary between $40 \%$ (lignin) to about 80 (cellulose) due to the evolution of $\mathrm{H}_{2} \mathrm{O}, \mathrm{CO}_{2}$, and volatile hydrocarbon (Qian et al., 2004). Wood consitutents are complexly bonded each other, so that they release various different compounds as

*1 Received on August 22, 2013; accepted on September 24, 2013

*2 Department of Forest Biomaterials Engineering, College of Forest \& Environmental Sciences, Kangwon National University, Chuncheon 200-701, Korea

*3 Korea Forest Research Institute, Seoul 130-172. Korea

† Corresponding author : Nam-Hun Kim (e-mail: kimnh@kangwon.ac.kr) 
pyrolysis proceeds. After the wood compounds are evaporated by metathesis, only charcoal is left over.

The mechanisms involved in the transition from wood to charcoal are known as follows; (1) evaporation of adsorbed water up to $150^{\circ} \mathrm{C}$, (2) splitting off of water in wood structure between $150^{\circ} \mathrm{C}$ and $260^{\circ} \mathrm{C}$, (3) chain scissions or depolymerization and breaking of $\mathrm{C}-\mathrm{O}$ and $\mathrm{C}-\mathrm{C}$ bonds within ring units evolving water, $\mathrm{CO}$ and $\mathrm{CO}_{2}$ between $260^{\circ} \mathrm{C}$ and $400^{\circ} \mathrm{C}$, and (4) formation of graphitic layers above $400^{\circ} \mathrm{C}$ (Greil, 2001). It has been also known that thermally induced decomposition and rearrangement reaction above $800^{\circ} \mathrm{C}$ are almost terminated leaving a carbon structure (Mopoung, 2008).

However, the mechanisms for wood carbonization are not fully understood because of the complexity caused by the varying physical and chemical properties of wood. In the previous researches (Kim and Hanna, 2006; Kwon and Kim, 2006; 2007; Kwon et al,. 2009), we reported the anatomical characteristics of the carbonized woods at different temperatures and the transition temperature from wood to charcoal. From our results, we understood the morphological change of wood cell wall layers from multilayered to amorphous structure and decomposition of cellulose crystal by increasing carbonization temperature.

In this study, we examined the change of calorific value, $\mathrm{pH}$ and FT-IR spectra in different temperatures in order to understand the transformation characteristics from wood to charcoal.

\section{MATERIAL and METHODS}

\subsection{Material}

Quercus variabilis woods obtained from the research forest of Kangwon National University in Chuncheon, Korea were used for this study.

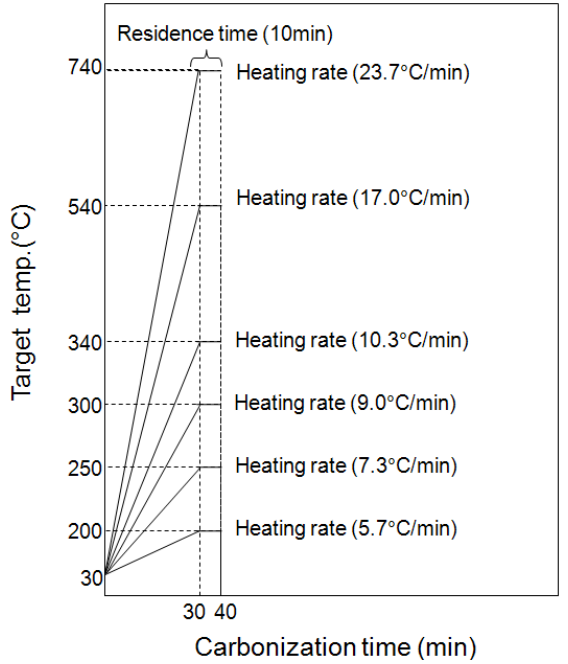

Fig. 1. Time-temperature profiles for wood carbonization with different heating rate.

Air-dried wood samples were cut into small blocks with the dimensions of $20 \mathrm{~mm}$ in thickness and width and $40 \mathrm{~mm}$ in length. The detail characteristics of sample tree has been described in previous work (Kwon and Kim, 2006).

\subsection{Methods}

\subsubsection{Carbonization Process}

Wood blocks were carbonized in an electric furnace under the nitrogen gas atmosphere (1 $\mathrm{kg} \mathrm{cm}{ }^{-2}$ ) at $200,250,300,340,540$, and $740^{\circ} \mathrm{C}$, respectively. The carbonization was carried out by heating the wood samples from room temperature to the final carbonization temperature. The samples were set to be heated for $30 \mathrm{mi}$ nutes to reach each targeted temperature. After reaching the final carbonization temperature, the samples were scheduled to keep for 10 minutes at constant temperature and then rapidly soaked into the sand for cooling. Heating rate of each target temperature are shown in Fig. 1. 


\subsubsection{Measurement of Heating Value}

The heating value of charcoal samples $(0.5 \mathrm{~g}$, 60 mesh) was measured by oxygen bomb calorimeter (Parr, 6300) in accordance with the KS E 3707 standard test method.

\subsubsection{Measurement of $\mathrm{pH}$ Value}

Oven-dried charcoal samples (1 g, 60 mesh) and $100 \mathrm{~m} \ell$ of distilled water were shaken together and boiled for 10 minutes. The samples left to settle for 10 minutes, and then $\mathrm{pH}$ was determined with a $\mathrm{pH}$ meter (inoLab, $\mathrm{pH}$ Level 2).

\subsubsection{FT-IR Spectroscopy}

To investigate the changes in the surface chemical properties during carbonization, FT-IR spectroscopy was used. The spectra were recorded on a BIO-RAD Cambridge, EXCALIBER Series FT-IR spectrometer in the range of $500-4,000 \mathrm{~cm}^{-1}$ wavenumber. In the preparation of pellets, wood chips were powdered and then mixed with $\mathrm{KBr}$ at an approximate ratio of $1 / 500$. Each pellet's mass was about $400 \mathrm{mg}$.

\section{RESULTS and DISCUSSION}

\subsection{Change of Heating Value}

Fig. 2 shows the change of the heating value of Quercus variabilis wood during carbonization at different temperatures. The heating value was gradually increased from $4,530 \mathrm{cal} / \mathrm{g}$ at $200^{\circ} \mathrm{C}$ to $8,030 \mathrm{cal} / \mathrm{g}$ at $740^{\circ} \mathrm{C}$. In our recent work (Kwon et al., 2012) we reported that heating value increased with increasing carbonization temperature from $6,800 \mathrm{cal} / \mathrm{g}$ at $400^{\circ} \mathrm{C}$ to $7,250 \mathrm{cal} / \mathrm{g}$ at $600^{\circ} \mathrm{C}$. Rhee and Cho (2008) reported that with increasing carbonization temperature, fuel ratio (fixed carbon/volatile combustible), carbon content, and heating value of

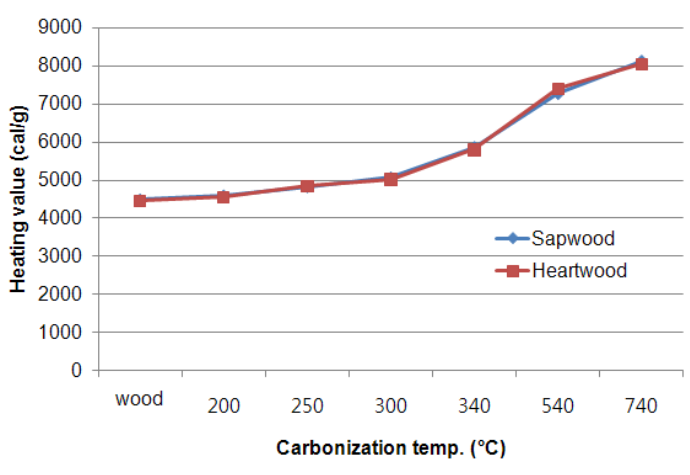

Fig. 2. The heating value of Quercus variabilis wood during carbonization at different temperatures.

carbonization residue increased but the yield of the residue decreased. Phan et al. (2008) examined the fuel properties of the slow pyrolysis products from three segregated waste materials (waste wood, cardboard and textile) heated at $350,400,500,600$, and $700^{\circ} \mathrm{C}$. They reported that the heating value was increased with increasing the charring temperature. Encinar et al. (1996, 2000) carried out the detailed study on the conventional pyrolysis of Cynara cardunculus, in order to determine the quality of the charcoal obtained in the process. They reported that the heating value increased with increasing carbonization temperature as the fixed carbon content increased. They also concluded that the most favourable pyrolysis temperature of residue from an energy point of view should be ranged between 600 and $700^{\circ} \mathrm{C}$, at which thus obtained charcoal would have a higher heating value and a suitable percentage of fixed carbon.

\subsection{Change of $\mathrm{pH}$ Value During Car- bonization}

The $\mathrm{pH}$ values of the wood and carbonized wood from 250 to $740^{\circ} \mathrm{C}$ are presented in Fig. 3. The $\mathrm{pH}$ value increased with increasing the carbonization temperatures. In this study, $\mathrm{pH}$ 
Change of Heating Value, pH and FT-IR Spectra of Charcoal at Different Carbonization Temperatures

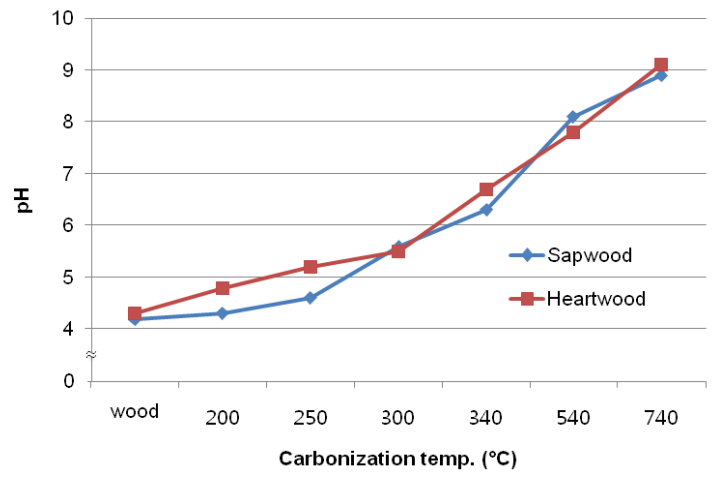

Fig. 3. The $\mathrm{pH}$ value of Quercus variabilis wood during carbonization at different temperatures.

value were low acidic until $340^{\circ} \mathrm{C}$, and changed to basic at over $540^{\circ} \mathrm{C}$. Recently, Kwon et al. (2012) also reported that $\mathrm{pH}$ value increased with increasing carbonization temperature from 7.6 at $400^{\circ} \mathrm{C}$ to 9.7 at $1200^{\circ} \mathrm{C}$. Yatagai et al. (1995) examined the $\mathrm{pH}$ of five kinds of charcoal prepared at 600 to $800^{\circ} \mathrm{C}$ by traditional black charcoal kiln. They found that $\mathrm{pH}$ values of most charcoal were ranged from 6.48 to 8.35. Jo et al. (2009) examined the properties and chemical bonding of wood charcoal carbonized at different temperatures. They reported that the $\mathrm{pH}$ become acidic to weakly basic for carbonized wood at about $300^{\circ} \mathrm{C}$, whereas it turned to basic at carbonization temperature higher than $600^{\circ} \mathrm{C}$.

\subsection{Change of Surface Chemical Pro- perty}

Fig. 4 shows FT-IR spectra from 500 4,000 $\mathrm{cm}^{-1}$ for Quercus variabilis wood. A strong hydrogen bonded $\mathrm{O}-\mathrm{H}$ stretching absorption was seen at $3,338 \mathrm{~cm}^{-1}$ and a prominent $\mathrm{C}-\mathrm{H}$ stretching absorption around 2,904 $\mathrm{cm}^{-1}$. In addition, there were many well-defined peaks in the region between 1,800 and $600 \mathrm{~cm}^{-1}$ (Table 1). The peaks in $1,734 \mathrm{~cm}^{-1}$ for non-conjugated $\mathrm{C}=\mathrm{O}$

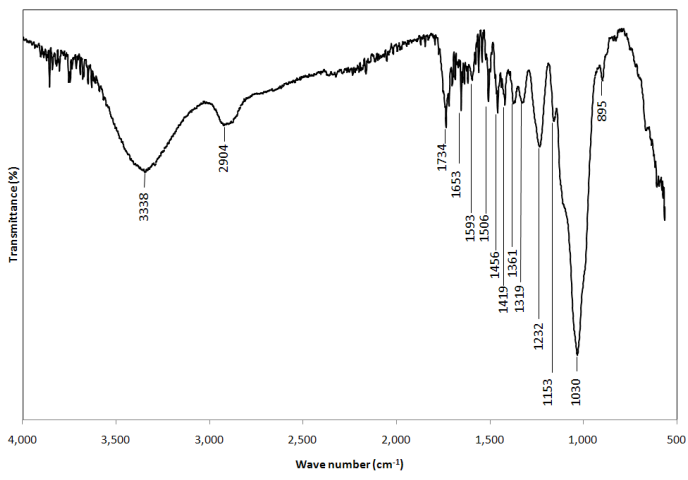

Fig. 4. FT-IR spectra of Quercus variabilis wood.

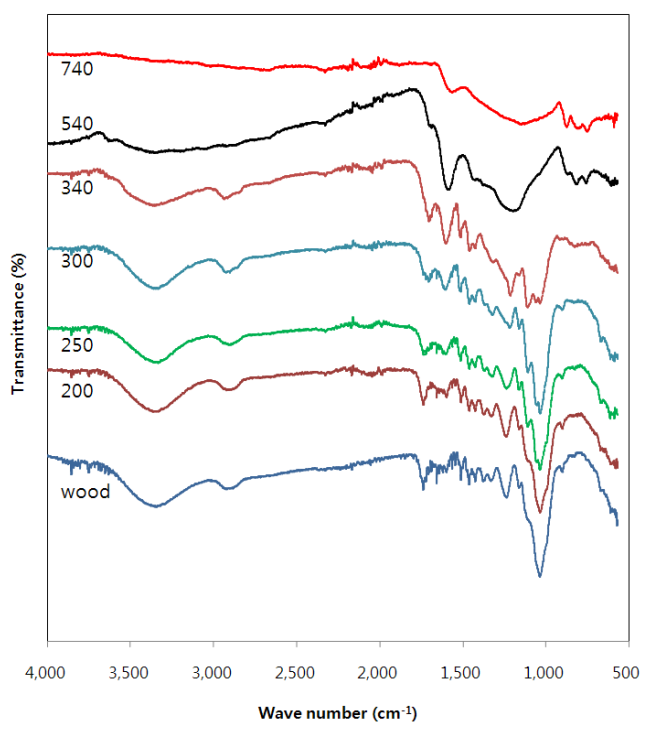

Fig. 5. FT-IR spectra of Quercus variabilis woods charred at different temperatures.

in xylans (hemicellulose), 1,653 $\mathrm{cm}^{-1}$ for conjugated $\mathrm{C}=\mathrm{O}$ in lignin, 1,593 and $1,506 \mathrm{~cm}^{-1}$ for aromatic skeletal in lignin, 1,456 and 1,419 $\mathrm{cm}^{-1}$ for $\mathrm{C}-\mathrm{H}$ deformation in lignin and carbohydrates, $1,361 \mathrm{~cm}^{-1}$ for $\mathrm{C}-\mathrm{H}$ deformation in cellulose and hemicellulose, $1,319 \mathrm{~cm}^{-1}$ for $\mathrm{C}-\mathrm{H}$ vibration in cellulose and $\mathrm{C}-\mathrm{O}$ vibration in syringyl derivatives, $1,232 \mathrm{~cm}^{-1}$ for syringyl ring 
Sung-Min Kwon, Jae-Hyuk Jang, Seung-Hwan Lee, Sang-Bum Park, and Nam-Hun Kim

Table 1. Peak assignment of FT-IR spectra peaks in Quercus variabilis wood

\begin{tabular}{cl}
\hline Wave number $\left(\mathrm{cm}^{-1}\right)$ & \multicolumn{1}{c}{ Peak assignment (Schwanninger et al., 2004) } \\
\hline \hline 3338 & O-H stretching \\
2904 & C-H stretching \\
1734 & Non-conjugated C=O in hemicellulose \\
1653 & Conjugated C=O in lignin \\
1593 & Aromatic skeletal vibration in lignin \\
1506 & Aromatic skeletal vibration in lignin \\
1456 & C-H deformation in lignin and carbohydrates \\
1419 & C-H deformation in lignin and carbohydrates \\
1361 & C-H deformation in cellulose and hemicellulose \\
1319 & C-H vibration in cellulose and \\
$\prime \prime$ & C-O vibration in syringyl derivatives \\
1232 & Syringyl ring and C-O stretch in lignin and xylan \\
1153 & C-O-C vibration in cellulose and hemicellulose \\
1030 & C-O stretch in cellulose and hemicellulose \\
895 & C-H deformation in cellulose \\
\hline
\end{tabular}

and $\mathrm{C}-\mathrm{O}$ stretch in lignin and xylan, $1,153 \mathrm{~cm}^{-1}$ for $\mathrm{C}-\mathrm{O}-\mathrm{C}$ vibration in cellulose and hemicellulose, $1,030 \mathrm{~cm}^{-1}$ for $\mathrm{C}-\mathrm{O}$ stretch in cellulose and hemicellulose and $895 \mathrm{~cm}^{-1}$ for $\mathrm{C}-\mathrm{H}$ deformation in cellulose.

Fig. 5 displays the FT-IR spectra of the wood sample and its chars obtained at different temperatures. At the temperature lower than $300^{\circ} \mathrm{C}$, the shape of the spectra was little changed, indicating almost no change in the chemical structure of the material. Wang et al. (2009) found that the charcoal of Chinese white pine prepared at $300^{\circ} \mathrm{C}$ showed the similar IR spectrum with complex transmittance bands with the raw sample. When the temperature was higher than $340^{\circ} \mathrm{C}$, however, the chemical structure of the samples started to change drastically, in good agreement with the result on X-ray diffraction analysis and trend in weight loss (Kwon and Kim, 2006). A broad band at $3,338 \mathrm{~cm}^{-1}$ was probably due to the hydrogen bonded $\mathrm{O}-\mathrm{H}$ stretching. In the temperature range of $200 \sim$ $300^{\circ} \mathrm{C}$, the intensity of $\mathrm{O}-\mathrm{H}$ band did not decrease noticeably. However, its intensity disappeared significantly at the temperature higher than $540^{\circ} \mathrm{C}$, implying the dehydration of wood. Sharma et al. (2004) characterized the functional change of lignin by heating with temperatures between 150 and $550^{\circ} \mathrm{C}$. They reported that the peak of the bonded $\mathrm{OH}$ stretch disappeared at $550^{\circ} \mathrm{C}$. The intensity of $(\mathrm{C}-\mathrm{H})$ band attributed to aliphatic $\mathrm{CH}_{2}$ and aromatic $\mathrm{CH}_{3}$ $\left(2904 \mathrm{~cm}^{-1}\right)$ decreased significantly between 340 and $540^{\circ} \mathrm{C}$. The bands arising from the stretching of the $1,734(\mathrm{C}=\mathrm{O}), 1,361(\mathrm{C}-\mathrm{H}), 1,153$ (C-O-C), 1,030 (C-O) and $895 \mathrm{~cm}^{-1}(\mathrm{C}-\mathrm{H})$ in cellulose and hemicellulose showed an evident decrease in intensity from wood to chars obtained at between 340 and $540^{\circ} \mathrm{C}$. Wang et al. (2009) reported that the striking evolution of $\mathrm{CO}_{2}$ and $\mathrm{CO}$ occurred at an onset temperature of $250^{\circ} \mathrm{C}$, with a peak temperature of around $350^{\circ} \mathrm{C}$. For the intensities of lignin, associated bands at 1,456, 1,419, 1,319 (C-H) and 1,232 $\mathrm{cm}^{-1}$ (C-O) decreased with increasing the carbonization temperature. These bands nearly disappeared between 340 and $540^{\circ} \mathrm{C}$. Aromatic skeletal vibration $\left(1,593\right.$ and $\left.1,506 \mathrm{~cm}^{-1}\right)$ showed maximum intensities at $540^{\circ} \mathrm{C}$. This result indicated the concomitant aromatization of a por- 
tion of residue upon the degradation of hemicellulose and lignin. A decrease of these bands at higher temperature reflected the carbonization by pyrolysis and the rebuilding of aromatic rings.

\section{CONCLUSION}

Quercus variabilis woods carbonized at 200, $250,300,340,540$ and $740^{\circ} \mathrm{C}$ were characterized. Heating value and $\mathrm{pH}$ increased with increasing carbonization temperature. From FT-IR spectroscopy, some chemical shifts were confirmed with increasing temperature.

The detailed characteristics are summarized as follows;

At the temperature range of 200 to $300^{\circ} \mathrm{C}$, $\mathrm{pH}$ and heating value were $4.6 \sim 5.65$ and 4,538 $\sim 5,020 \mathrm{cal} / \mathrm{g}$, respectively. The FT-IR spectra was not significantly changed in this temperature range. At $340^{\circ} \mathrm{C}, \mathrm{pH}$ and heating value were found to be ca. 6.5 and $5,800 \mathrm{cal} / \mathrm{g}$, respectively. The intensities of absorption bands from cellulose and hemicellulose in FT-IR spectra almost disappeared and the aromatization process started at this temperature. At $540^{\circ} \mathrm{C}$, $\mathrm{pH}$ and heating value were found to be ca. 8 and 7,400 cal/g, respectively. The intensities of FT-IR absorption bands from cellulose, hemicellulose and lignin were almost absent and only a small amount of ether typed structures were retained. At $740^{\circ} \mathrm{C}, \mathrm{pH}$ and heating value were ca. 9 and $8,000 \mathrm{cal} / \mathrm{g}$, respectively. The intensities of FT-IR absorption bands from cellulose, hemicellulose and lignin almost disappeared.

\section{REFERENCES}

1. Encinar, J. M., F. J. Beltrán, A. Bernalte, A. Ramiro, and J. F. González. 1996. Pyrolysis of two agricultural residues: Olive and grape bagasse. Influence of particle size and temperature Biomass and Bioenergy 11(5): 397 409.

2. Encinar, J. M., J. F. González, and J. González. 2000. Fixed-bed pyrolysis of Cynara cardunculus L. product yields and compositions. Fuel Processing Technology 68(3): 209 222.

3. Greil, P. 2001. Biomorphous ceramics from lignocellulosics. Journal of the European Ceramic Society 21: $105 \sim 118$.

4. Jo, T. S., O. K. Lee, J. W. Choi, S. T. Cho, and S. K. Kim. 2009. Changes of chemical bond in woody charcoal from different carbonization temperatures. Journal of the Wood Science and Technology 37(1): 87 93.

5. Kim, N. H. and R. B. Hanna. 2006. Morphological characteristics of Quercus variabilis charcoal prepared at different temperatures. Wood Science and Technology 40(5) : 392 401.

6. Kwon, S. M. and N. H. Kim. 2006. Investigation of carbonization mechanism of wood (I). Journal of the Wood Science and Technology 34(3): $8 \sim 14$.

7. Kwon, S. M. and N. H. Kim. 2007. Investigation of carbonization mechanism of wood (II). Journal of the Wood Science and Technology 35(3): $45 \sim 52$.

8. Kwon S. M., G. J. Kwon, J. H. Jang, and N. H. Kim. 2012. Characteristics of charcoal in different carbonization temperatures. Journal of Forest Science 28(4): 263 267.

9. Kwon, S. M., N. H. Kim, and D. S. Cha. 2009. An investigation on the characteristics of the wood cells during carbonization. Wood science and technology 43: 487 498.

10. Mopoung, S. 2008. Surface image of charcoal and activited charcoal from banana peel. Journal of Microscopy Society of Thailand 22: 15 19.

11. Phan, A. N., C. Ryu, V. N. Sharifi, and J. Swithenbank. 2008. Characterization of slow pyrolysis products from segregated wastes for energy production. Journal of Analytical and Applied Pyrolysis 81: 65 71.

12. Qian, J. M., J. P. Wang, G. J. Qiao, and Z. H. Jin. 2004. Preparation of porous $\mathrm{SiC}$ ceramic with a woodlike microstructure by sol-gel and carbothermal reduction processing. Journal of the European Ceramic Society 24: 3251 3259.

13. Rhee, S. W. and Y. H. Cho. 2008. A study on 
Sung-Min Kwon, Jae-Hyuk Jang, Seung-Hwan Lee, Sang-Bum Park, and Nam-Hun Kim

characteristics of carbonization residue produced from woody biomass. Journal of Korea Solid Wastes Engineering Society 25(6): 533 539.

14. Schwanninger, M., J. C. Rodriguesc, H. Pereirac, and B. Hinterstoisser. 2004. Effects of short-time vibratory ball milling on the shape of FT-IR spectra of wood and cellulose. Vibrational Spectroscopy 36: $23 \sim 40$.

15. Sharma, R. K., J. B. Wooten, V. L. Baliga, X. Lin, W. G. Chan, and M. R. Hajaligol. 2004. Characterization of chars from pyrolysis of lignin.
Fuel 83: 1469 1482.

16. Wang, Z., J. Cao, and J. Wang. 2009. Pyrolytic characteristics of pine wood in a slowly heating and gas sweeping fixed-bed reactor. Journal of Analytical and Applied Pyrolysis 84: 179 184.

17. Yatagai, M., R. Ito, T. Ohira, and K. Oba. 1995. Effect of charcoal on purification of wastewater. Mokuzai Kakkaishi 41(4): 425 432.

18. Zeriouh, A. and L. Belkbir. 1995. Thermal decomposition of a Moroccan wood under a nitrogen atmosphere. Thermochimica Acta 258: 243 248. 